\title{
The morbidity and mortality rates in patients with renal cell carcinoma in Ukraine
}

Renal cell carcinoma (RCC) accounts for about $3 \%$ of all cancers in adults and $90 \%$ of all kidney tumors. Over the last 10 decade a significant increase in the incidence of this tumor is observed as evidenced by statistical data. Thus, the incidence in Ukraine between 1994 and 2004 had increased from 6,6 to 9,4 (crude marker) per 100000 population [1], the number of reported cases of RC was 3459 in 1998 compared to 4466 in 2004 (increased by $23 \%$ ) [2]. According to the World Health Organization kidney cancer morbidity ranks $13^{\text {th }}$ among all cancers; approx. 270000 of newly diagnosed RCC cases are reported each year, and approximately 116000 patients die each year from the disease [3, 4].

In the US, the incidence of RCC is about $4 \%$ of all malignant tumors diagnosed. In 201264770 new cases of RCC were diagnosed in the US with a trend to predominance of more frequent occurrence in male patients at a ratio of 3:2. Large-scale study SEER (Surveillance, Epidemiology and End Results) indicated that approximately 1 in 69 men and 1 in 116 women with diagnosed RCC will be diagnosed with RCC throughout their lives [5]. Number of deaths due to the disease has reached 13500 by 2012. Despite the fact that over the past 10 years mortality rates in patients with RCC in the United States remain almost unchanged, there is an annual increase in the incidence of this disease, which is reported by numerous epidemiological studies [6].

Given the above, the issue of monitoring and analysis of morbidity and mortality rates in RCC in Ukraine and its regions is extremely relevant for the contemporary oncourology.

Objective. The purpose of the study was to analyze the morbidity and mortality rates in RCC in Ukraine and its regions in recent years.

Materials and methods. The analysis of morbidity and mortality rates in RCC in Ukraine was carried out according to the Bulletin of the National Cancer Registry of Ukraine, 1999-2014. The following indices were

(C) Мицик Ю.О., 2015 
analyzed: crude morbidity and mortality markers representing the number of newly diagnosed cases of malignant neoplasms (or, respectively, cases of death from malignant tumors), that occurred in the population during the year divided by the average number of population in the same year, in terms of the rate per 100000 population; age standardized morbidity and mortality rates - morbidity (mortality) rate of the population, calculated by age structure for the "standard population" in order to level the differences in the age distribution of various populations. Extensively used for comparisons between countries world standard population and standard Ukrainian population, calculated on the basis of the age structure of the population of Ukraine in 2000, were selected as standard populations.

Results and discussion. The analysis of crude and standardized morbidity rate of RCC in Ukraine between 1999 and 2014 trend towards increase of both indices was observed. Thus, in 1999 crude RCC morbidity rate was 8,0 in $2004-9,8$, in $2005-10,3$, in $2006-10,3$, in $2007-$ 11,1 , in $2008-11,5$, in $2009-11,2$, in $2010-11,9$, in $2011-12,3$, in $2012-12,8$, in $2013-12,7$, in $2014-12,9$. Herewith, crude morbidity rate was, on average, 1,5 times higher in men than in women. Similar dynamics was observed in the change of the standardized RCC morbidity rate: in 1999 it was 5,6, in $2004-6,5$, in $2005-6,8$, in $2006-6,7$, in $2007-7,4$, in $2008-7,6$, in $2009-7,34$, in $2010-7,6$, in $2011-$ 7,8 , in $2012-8,1$, in $2013-8,2$, in $2014-8,3$ Wherein, this index was almost twice as high in men as in women.

The analysis of the dynamics of changes in crude mortality rates due to RCC in Ukraine demonstrated increment change compared to previous years: in 1999 it was 4.3 , in $2004-5,1$, in $2005-4,9$, in $2006-5,1$, in $2007-5,4$, in $2008-5,3$, in $2009-5,32$, in $2010-5$, 5 , in $2011-$ 5,4 , in $2012-5,5$, in $2013-5,4$, in $2014-5,5$. In men, this index was on average twice as high as in women. Standardized mortality rate due to RCC increased in the period between 1999 and 2004, though remained relatively stable from 2004 to 2014 with minor increment growth: in 1999 it was 2,8 , in $2004-3,2$, in $2005-3,2006-3,1$, in $2007-3,3$, in $2008-3,3$, in $2009-3,2$, in $2010-3,2$, in $2011-3,1$, in $2012-$ 3,2 , in $2013-3,1$, in $2014-3,2$. Herewith, this index was almost 3 times higher in men than in women.

In analysis of the dynamics of standardized RCC morbidity rate (Ukrainian standard) in Ukraine and its regions during 1999-2014 a steady increment growth compared to previous years was observed. Thus, in 1999 it was 8,1 , in $2004-9,4$, in $2005-9,8$, in $2006-9,8$, in $2007-10,8$, $2008-11,2$, in $2009-10,82$, in $2010-11,2$, in $2011-11$, in $2012-$ 12,1 , in $2013-12,2$, in $2014-12,3$. Thus, in 2014 it was the highest in the following regions: Sumy $-15,5$, Nikolaev - 14, Kirovograd - 13,8, Rivne - 13,7, and in Poltava - 13,7, and the lowest in Chernivtsi - 7,6, Transcarpathian $-7,7$ and Cherkassy $-10,1$ regions (Table).

Assessment of RCC mortality rates dynamics (Ukrainian standard) in different regions of Ukraine allowed to establish the highest mortality rates in Zaporizhzhya -7 , Sumy -6 , Rivne -6 , Ternopil $-5,9$, and Poltava regions $-5,9$. The lowest RCC mortality rate has been observed in Odessa - 3,7, Cherkassy - 4, Transcarpathian region $-4,2$, and Chernivtsi $-4,2$.

Conclusions. The analysis of the dynamics of the RCC morbidity in 1999-2014 demonstrated incremental growth in Ukraine a as whole and in each particular region. In 1999 RCC morbidity rate (world standard) in Ukraine was 5,6 and in $2014-8,3$. Herewith, given index in males was, on average, twice as high as in females. The analysis of RCC mortality dynamics in 1999-2014 showed a clear trend to increment growth in Ukraine as a whole and in each particular region. In 1999 RCC mortality rate (world standard) in Ukraine was 2,8 and in $2014-3,2$. However, 


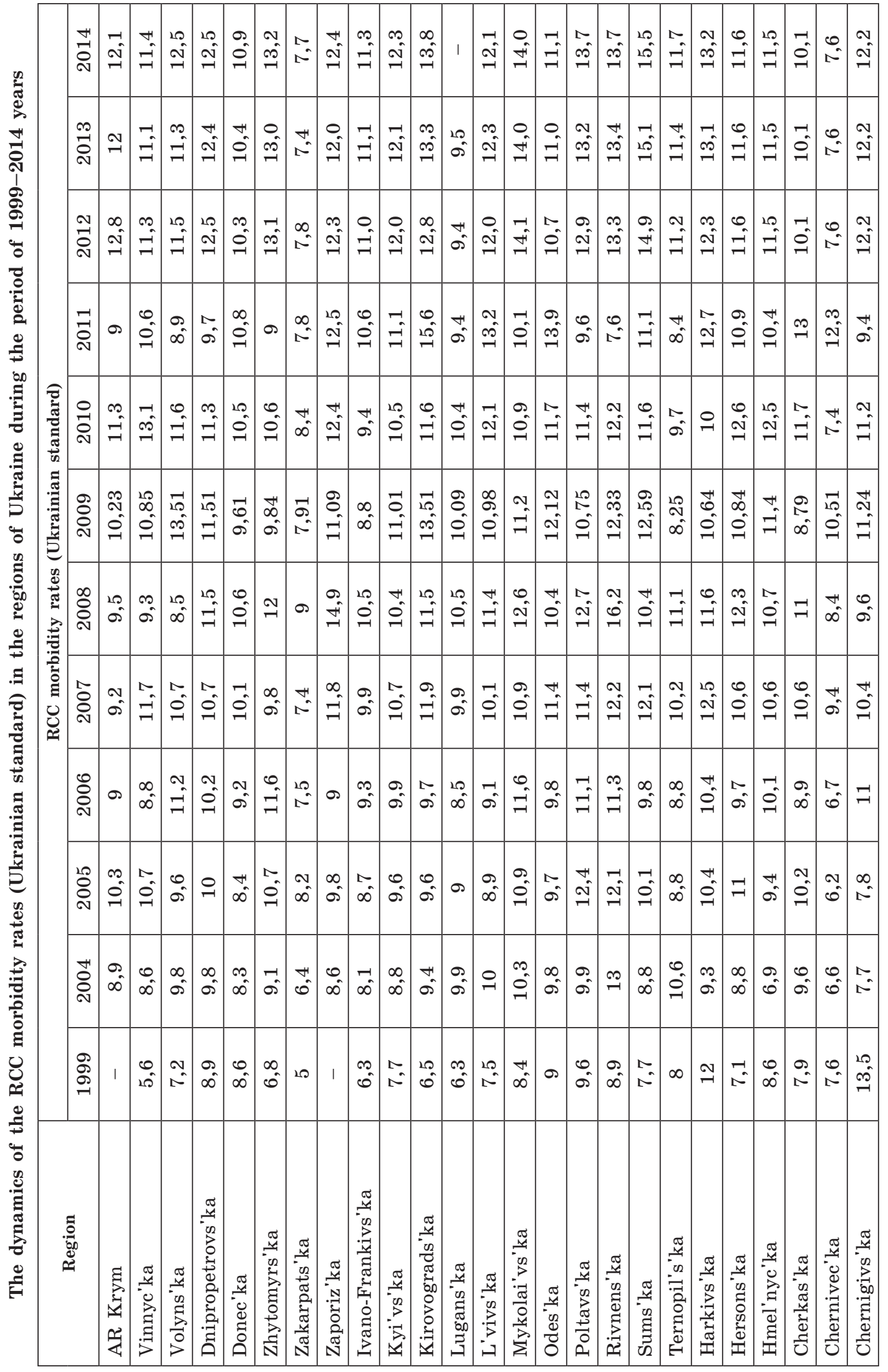


this index was almost 3 times higher in males than in females. Continuous increment growth of morbidity and mortality in patients with RCC requires revision of protocols of diagnostics and treatment of such patients.

\title{
REFERENCES
}

1. Федоренко З.П. Рак в Україні. 2012-2013. / З.П. Федоренко, Ю.Й. Михайлович, Л.О. Гулак [та ін.] Бюлетень національного канцер-реєстру України. - 2014. - № 15. 124 c. (Fedorenko Z. Rak v Ukraini, 2012-2013 / Z. Fedorenko, J. Myhajlovych, L. Gulak [et al.] // Bjuleten nacionalnogo kancer-rejestru Ukrainy. - 2014. - N 15. - P. 1-124). 2. Ferlay J. Estimates of worldwide burden of cancer in 2008 : Globocan 2008 / J. Ferlay, H. Shin, F. Bray [et al.] // Int. J. Cancer. - 2010. - N 12. - P. 893-917. 3. Jemal A. Global cancer statistics / A. Jemal, F. Bray, M. Center [et al.] // CA Cancer J. Clin. 2011. - N 2. - P. 69-90. 4. Jemal A. Cancer statistics, 2010 / A. Jemal, R. Siegel, J. Xu, E. Ward [et al.] // CA Cancer J. Clin. - 2010. - N 5. - P. 277-300. 5. Gloeckler L. Cancer survival and incidence from the Surveillance, Epidemiology, and End Results (SEER) program / L. Gloeckler, M. Reichman, D. Lewis [et al.] // Oncologist. - 2003. N 6. - P. 541-552. 6. Siegel R. Cancer statistics, 2012 / R. Siegel, D. Naishadham, A. Jemal [et al.] // CA Cancer J. Clin. - 2012. - N 1. - P. 10-29.

Стаття надійшла до редколегії 07.06.2015

\section{ЗАХВОРЮВАНІСТЬ І СМЕРТНІСТЬ ВІД РАКУ НИРКИ В УКРАЇНІ}

\author{
Ю.О. МИЦИК
}

Львівський національний медичний університет іл. Данила Галицького

Нирково-клітинний рак (НКР) становить близько 3 \% усіх злоякісних пухлин у дорослих і понад $90 \%$ усіх новоутворень нирки. За останне 10-річчя значно зросла захворюваність на цю пухлину, про що свідчать статистичні дані.

Проаналізовано показники захворюваності й смертності від НКР в Україні загалом та в регіонах за останні роки.

Показників захворюваності й смертності на НКР проаналізовано за даними Бюлетеня Національного канцер-реєстру України 1999-2014 рр. Проаналізовано такі показники: грубі (звичайні) показники захворюваності й смертності, стандартизовані за віком показники захворюваності й смертності, широко вживаний для порівняння показників між різними країнами світовий стандарт населення, а також український стандарт населення, визначений на основі вікової структури населення країни в 2000 р.

Аналіз показників захворюваності на НКР (1999-2014) продемонстрував їх зростання як у країні загалом, так і в областях. У 1999 р. показник захворюваності (світовий стандарт) на НКР в країні становив 5,6, а в 2014 р. - 8,3. У чоловіків цей показних був у середньому вдвічі вищий, ніж у жінок. Аналіз показників смертності внаслідок НКР у 1999-2014 рр. засвідчив чітку тенденцію до їх зростання. У 1999 р. показник смертності (світовий стандарт) унаслідок НКР в країні становив 2,8, а в 2014 р. - 3,2 і був майже втричі вищий у чоловіків, ніж у жінок.

Дослідження показало чітку тенденцію до зростання показників захворюваності й смертності у хворих із НКР в країні та в областях в 1999-2014 рр. При цьому спостерігались гендерні особливості - у чоловіків обидва показники були значно вищі, ніж у жінок. Невпинне зростання захворюваності й смертності у хворих із НКР потребує перегляду протоколів обстеження та лікування.

Ключові слова: нирково-клітинний рак, захворюваність, смертність.

\section{ЗАБОЛЕВАЕМОСТЬ И СМЕРТНОСТЬ ОТ РАКА ПОЧКИ В УКРАИНЕ Ю.О. МЫЦИК}

Львовский национальный медицинский университет ил. Данила Галицкого

Почечно-клеточный рак (ПКР) составляет приблизительно 3 \% всех злокачественных опухолей у взрослых и более $90 \%$ всех новообразований почки. В последние 10 лет отмечается значительное повышение заболеваемости, о чем свидетельствуют статистические данные.

Проанализированы показатели заболеваемости и смертности больных с ПКР в стране в целом и в регионах в 1999-2014 гг. 
Показатели заболеваемости и смертности среди больных с ПКР взяты из Бюллетеня Национального канцер-реестра Украины 1999-2014 гг. Проанализированы следующие показатели: грубые (обычные) показатели заболеваемости и смертности, стандартизированные согласно возрасту показатели заболеваемости и смертности; широко используемый для сравнения показатель между различными странами мировой стандарт населения, а также украинский стандарт населения, рассчитанный на основе возрастной структуры населения в 2000 г.

Проведенный анализ продемонстрировал увеличение показателей заболеваемости и смертности у больных с ПКР в 1999-2014 гг. как в целом по стране, так и в областях. В 1999 г. показатель заболеваемости (мировой стандарт) у больных с ПКР составлял 5,6, в 2014 г. - 8,3. При этом у мужчин данный показатель превышал таковой у женщин в среднем в 2 раза. Анализ динамики показателей смертности вследствие ПКР в 1999-2014 гг. показал четкую тенденцию к ее увеличению как по стране в целом, так и в областях. В 1999 г. смертность от ПКР по стране составляла 2,8, а в 2014 г. - 3,2. При этом данный показатель был почти в 3 раза выше у мужчин, чем у женщин.

В результате проведенного исследования установлена четкая тенденция к возрастанию показателей заболеваемости и смертности у больных с ПКР по стране в целом и в областях в 1999-2014 гг. При этом отмечались гендерные особенности - у мужчин оба показателя значительно превышали таковые у женщин. Непрерывный рост заболеваемости и смертности от ПКР требует пересмотра протоколов диагностики и лечения такой категории больных.

Ключевые слова: почечно-клеточный рак, заболеваемость, смертность. 